University of Nebraska - Lincoln

DigitalCommons@University of Nebraska - Lincoln

1964

Geographic Distribution of Some Species of Trichodinids (Ciliata: Peritricha) Parasitic on Fishes

\author{
Glenn L. Hoffman \\ US Fish and Wildlife Services \\ Jiří Lom \\ Bureau of Sport Fisheries and Wildlife
}

Follow this and additional works at: https://digitalcommons.unl.edu/usfwspubs

Part of the Aquaculture and Fisheries Commons

Hoffman, Glenn L. and Lom, Jiří, "Geographic Distribution of Some Species of Trichodinids (Ciliata: Peritricha) Parasitic on Fishes" (1964). US Fish \& Wildlife Publications. 105.

https://digitalcommons.unl.edu/usfwspubs/105

This Article is brought to you for free and open access by the US Fish \& Wildlife Service at DigitalCommons@University of Nebraska - Lincoln. It has been accepted for inclusion in US Fish \& Wildlife Publications by an authorized administrator of DigitalCommons@University of Nebraska - Lincoln. 


\title{
Geographic Distribution of Some Species of Trichodinids (Ciliata:Peritricha) Parasitic on Fishes
}

\author{
Jiři Lom and Glenn L. Hoffman \\ Protozoological Department of the Institute of Parasitology of the Czechoslovak Academy of \\ Sciences, Praha, and Bureau of Sport Fisheries and Wildlife, Eastern Fish Disease Laboratory, \\ Kearneysville, West Virginia
}

\begin{abstract}
North American Trichodina from Carassius auratus, Lepomis cyanellus, L. macrochirus, Micropterus salmoides, and Rhinichthys atratulus have been studied by the silver-impregnation method and compared with European species. T. reticulata Hirschmann and Partsch, 1955, and T. (Foliella) subtilis Lom, 1959, originally described from European goldfish, are herein recorded from North America also. T. fultoni Davis, 1947, from Lepomis cyanellus, Micropterus salmoides, and Rhinichthys atratulus is redescribed, and T. domerguei f. magna Lom, 1961, described from European tench and gudgeon, is considered a synonym. A Trichodina sp. from the gills of Lepomis macrochirus is described; it is almost identical with T. nigra Lom, 1961 from European Rutilus, T. discoidea from centrarchids, and T. tumefaciens from Cottus of North America. Other North American trichodinids are reviewed briefly.
\end{abstract}

Up to the present time, more than 90 species of Trichodina have been described from the gills and skin of marine and freshwater fishes. Many of them have been considered as new only because they were found in a different host and remote geographic area. The descriptions in many cases were inadequate since the uniform body structure of these ciliates yields few characters for solid differentiation of species. However, the recently employed Klein's silver-impregnation technique (Lom, 1958; Raabe, 1959) clearly reveals details of the adhesive disc which are important features of urceolariid taxonomy. This, together with careful biometrical and other morphological information, represents a good base for taxonomic studies of this group. It is beyond the scope of this communication to present all the problems of trichodinid taxonomy; they can be found in Uzmann and Stickney (1954), Raabe (1959), and Lom (1958, 1961, 1962).

Though insufficient description of some species does not permit us to identify them again, reexamination of a number of species which have been accurately characterized by older methods is possible. This is a study on the geographic distribution of some fish trichodinids, based on a comparison of four species

Received for publication 9 April 1963. from some North American fishes from Pennsylvania and West Virginia with material from Czechoslovakia.

\section{Trichodina reticulata Hirschmann and Partsch, 1955}

Host: Carassius auratus, on skin.

Locality: Mt. Parnell Fisheries, Mercersburg, Pennsylvania.

Numerous typical individuals of this parasite were found in March 1962. T. reticulata is characterized by the peculiar cell-like structure of the center of the adhesive disc. Its biometrical data agree fully with populations found on the skin of crucian carp, C. carassius, in Czechoslovakia and Poland. The goldfish, C. auratus,${ }^{1}$ was introduced to North America from East Asia (China and Japan) and has retained the trichodinids from its original country. This finding suggests that $T$. reticulata is typical for crucian carp throughout the area of its present geographic distribution.

Trichodinella (Foliella) subtilis Lom, 1959

Host: Carassius auratus, on gills.

Locality: Mt. Parnell Fisheries, Mercersburg, Pennsylvania.

A few individuals were found in smears made from the gills of the host. Its morphology in the impregnated preparations agrees with the description of T. (F.) subtilis of gills of crucian carp in Europe.

\footnotetext{
${ }^{1}$ C. carassius and $C$. auratus are considered varieties of the same species (Eddy, personal communication).
} 
TABLE I. Biometric comparison of Trichodina fultoni of Davis (1947), our findings, and T. domerguei f. magna.

\begin{tabular}{|c|c|c|c|}
\hline & Trichodina fultoni & Trichodina fultoni & $\begin{array}{l}\text { Trichodina domerguei } \\
\text { f. magna }\end{array}$ \\
\hline Author of data & Davis, 1947 & Our findings & Lom, 1961 \\
\hline Host & $\begin{array}{l}\text { Lepomis macrochirus, } \\
\text { Micropterus salmoides, } \\
\text { M. dolomieu, } \\
\text { Ambloplites rupestris, } \\
\text { Salmo irideus }\end{array}$ & $\begin{array}{l}\text { Lepomis cyanellus, } \\
\text { Rhinichthys atratulus, } \\
\text { M. salmoides }\end{array}$ & $\begin{array}{l}\text { Tinca tinca, } \\
\text { Nemachilus barbatulus }\end{array}$ \\
\hline Locality & $\begin{array}{l}\text { Fish and Wildlife Hatchery, } \\
\text { Kearneysville, W. Va. }\end{array}$ & $\begin{array}{l}\text { Fish and Wildlife Hatchery, } \\
\text { Kearneysville, W. Va. }\end{array}$ & $\begin{array}{l}\text { Bohemia in Czechoslovakia, } \\
\text { Europe }\end{array}$ \\
\hline Location & Gills and skin & Gills and skin & Skin \\
\hline Diameter of the body & about $100 \mu$ & $101(91-112) \mu$ & $98(82-111) \mu$ \\
\hline Diam of the adhesive disc & $75-90 \mu$ & $78(71-86) \mu$ & $77(62-82) \mu$ \\
\hline Diam of the denticulate ring & $50-58 \mu$ & $52(47-58) \mu$ & $47(41-55) \mu$ \\
\hline Number of denticles & $27-29(25-30)$ & $28(26-31)$ & $27(25-31)$ \\
\hline $\begin{array}{l}\text { Number of radial pins } \\
\text { per denticle }\end{array}$ & $12-14$ & $12-14$ & $13-14$ \\
\hline $\begin{array}{l}\text { Dimensions of denticles: } \\
\text { length of thorn }\end{array}$ & $-^{1}$ & $5.5 \mu$ & $6 \mu$ \\
\hline Length of blade & - & $6.5 \mu$ & $7.5 \mu$ \\
\hline Length of denticle & - & $12.5 \mu$ & $17 \mu$ \\
\hline Width, central part & - & $4 \mu$ & $4.5 \mu$ \\
\hline Width, border membrane & - & $5-7 \mu$ & $5-7 \mu$ \\
\hline Diam macronucleus & - & $65-74 \mu$ & $58-69 \mu$ \\
\hline Micronucleus & Difficult to find & Could not be detected & $\begin{array}{l}1.5 \times 3 \mu \text { but difficult } \\
\text { to detect }\end{array}$ \\
\hline
\end{tabular}

${ }^{1}$ Information not given.

\section{Trichodina fultoni Davis, 1947}

Host: Lepomis cyanellus, Micropterus salmoides, Rhinichthys atratulus, on gills and skin.

Locality: Kearneysville, West Virginia.

Specimens were collected from the same locality as Davis' (1947) original North American material from M. salmoides and other centrarchids; they were easily recognized as identical with those found in Czechoslovakia on the skin of Tinca tinca and Nemachilus barbatulus. Lom (1961) identified the same ciliate in Czechoslovakia as Trichodina domerguei because of the clear area in the center of the adhesive disc which is a differential feature (Raabe, 1959). However, because his specimens showed certain significant differences from Raabe's form, Lom (op. cit.) designated his ciliate, provisionally, $T$. domerguei f. magna; at that time it was impossible to compare it with the North American species described by Mueller (1937), MacLennan (1939), and Davis (1947) because certain details were lacking in the descriptions. Although two species may have almost identical measurements, their morphology may be significantly different.

The biometrical data for the present specimens agree with both $T$. fultoni Davis and $T$. domerguei f. magna (Table I). Both are smaller than $T$. truttae Mueller, 1937, but much larger than other North American species. The shape of the den- ticles in Davis' (1947) illustrations of T. fultoni, although stained with usual histological methods, agrees with that found in the trichodinids from L. cyanellus, $R$. atratulus, and $M$. salmoides in North America and in T. domerguei f. magna from Europe. The peculiar grains in the center of the clear area are also discernible in Davis' pictures. Because of priority all these ciliates should be designated T. fultoni Davis, 1947.

We would like to call attention to the evanescence of the central clear area during division (Figs. A to F). It divides in two, then disappears at the time when the new ciliate, bearing half the adult number of denticles, forms the new denticulate ring. The original clear area then quickly reappears.

\section{Trichodina sp. (? T. nigra Lom, 1961)}

Host: Lepomis macrochirus, Micropterus salmoides, on gills.

Locality: Hatchery ponds, Kearneysville, West Virginia.

This species was numerous on 8-month-old $L$. macrochirus in March 1962. The biometrical data are close to those given for $T$. nigra f. cobitis Lom, 1961, T. discoidea Davis, 1947, and T. tumefaciens Davis, 1947, all of which display considerable variability (Table II). It most nearly resembles $T$. nigra $\mathrm{f}$. cobitis but the thorns of the denticles 


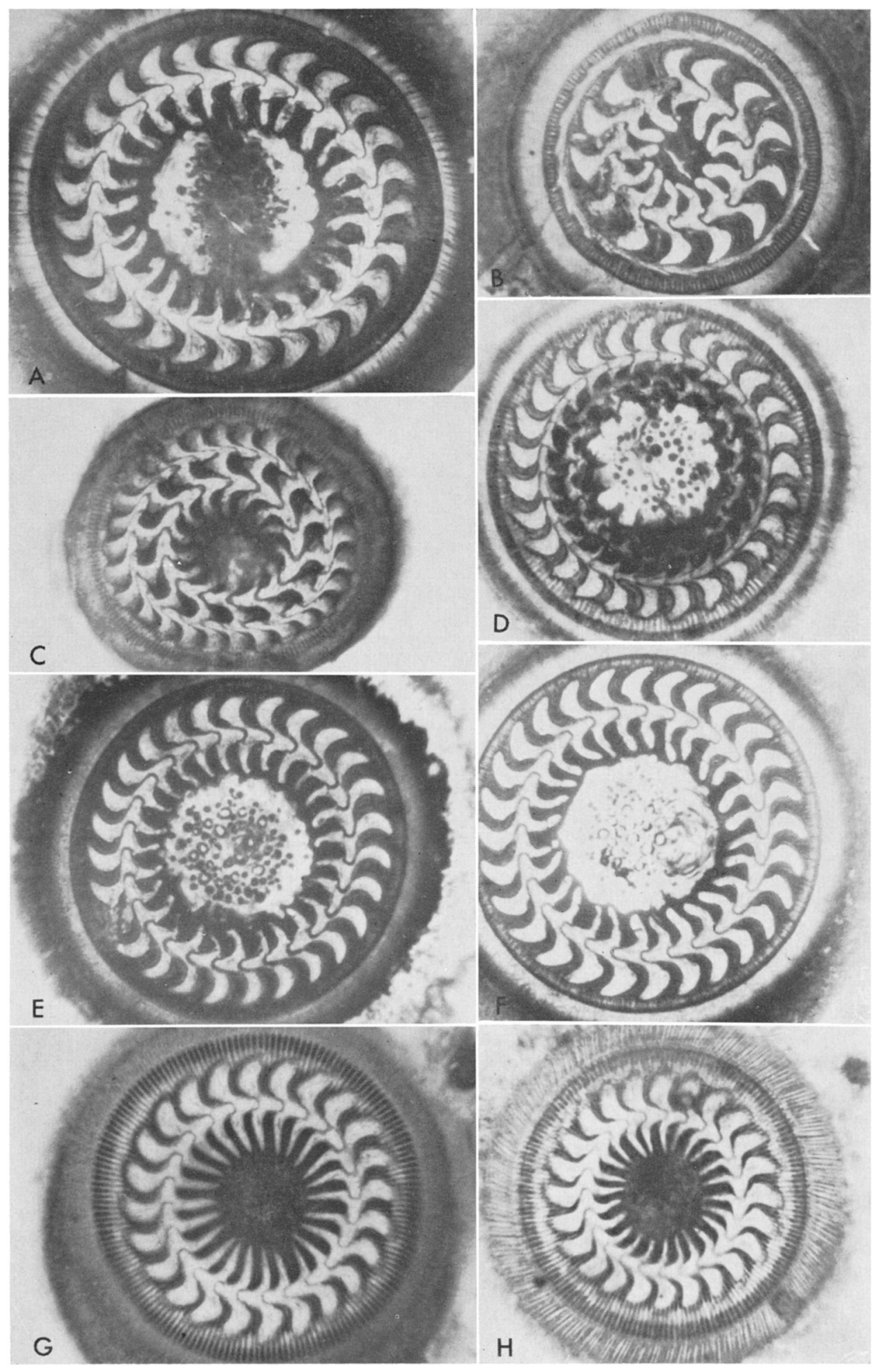

Figures A to $\mathrm{H}$. 
TABLE II. Biometric comparison of Trichodina sp. (? T. nigra), T. discoidea, T. tumefaciens, and T. nigra $f$. cobitis.

\begin{tabular}{|c|c|c|c|c|c|}
\hline & \multicolumn{2}{|c|}{$\begin{array}{c}\text { Trichodina } \\
\text { sp. (? T. nigra) }\end{array}$} & $\begin{array}{l}\text { Trichodina } \\
\text { discoidea }\end{array}$ & $\begin{array}{l}\text { Trichodina } \\
\text { tumefaciens }\end{array}$ & $\begin{array}{l}\text { Trichodina nigra } \\
\text { f. cobitis }\end{array}$ \\
\hline $\begin{array}{l}\text { Author of } \\
\text { description }\end{array}$ & Our findings & & Davis, 1947 & Davis, 1947 & Lom, 1961 \\
\hline Host & $\begin{array}{l}\text { Lepomis } \\
\text { macrochirus }\end{array}$ & $\begin{array}{l}\text { Micropterus } \\
\text { salmoides }\end{array}$ & $\begin{array}{l}\text { Lepomis macro- } \\
\text { chirus, Pomoxis } \\
\text { sparoides, } \\
\text { Ambloplites } \\
\text { rupestris, } \\
\text { Ictalurus } \\
\text { punctatus } \\
\end{array}$ & Cottus bairdii & Cobitis taenia \\
\hline Locality & $\begin{array}{l}\text { Kearneysville, } \\
\text { W. Va. }\end{array}$ & $\begin{array}{l}\text { Kearneysville, } \\
\text { W. Va. }\end{array}$ & $\begin{array}{l}\text { Kearneysville, } \\
\text { W. Va. }\end{array}$ & $\begin{array}{l}\text { Kearneysville, } \\
\text { W. Va. }\end{array}$ & Bohemia, CSSR \\
\hline Location & Gills & Gills & Gills & Gills & Gills \\
\hline Diam of the body & $50(46-55) \mu$ & $52-58 \mu$ & - & - & $55(41-58) \mu$ \\
\hline $\begin{array}{l}\text { Diam of the } \\
\text { adhesive disc }\end{array}$ & $36(32-42) \mu$ & $40(35-45) \mu$ & $35-50 \mu$ & $29-38 \mu$ & $35(32-38) \mu$ \\
\hline $\begin{array}{l}\text { Diam of the den- } \\
\text { ticulate ring }\end{array}$ & $20(18-23) \mu$ & $25(22-29) \mu$ & $19-29 \mu$ & $18-23 \mu$ & $21(20-24) \mu$ \\
\hline $\begin{array}{l}\text { Number of } \\
\text { denticles }\end{array}$ & $24(22-25)$ & $23(20-25)$ & $20-25(18-30)$ & $21-25(19-26)$ & $25(23-30)$ \\
\hline
\end{tabular}

of our specimens lack the thicker central axis of the typical $T$. nigra from Rutilus. Lacking any striking morphological differences to aid in identification, we have designated this form T. nigra (?). The specimens obtained from L. macrochirus agree so closely with those from $M$. salmoides that we assume they are identical.

\section{DISCUSSION}

It is likely that parasitic protozoa of fish which are not dependent on an intermediate host will be distributed along with their hosts to new geographic areas. There is little doubt that T. (Foliella) subtilis and T. reticulata have been transferred with the goldfish host from Asia to both Czechoslovakia and North America. One very serious protozoan disease of fish culture, whirling disease of trout, caused by Myxosoma cerebralis, has spread all over Europe and Asia (Bauer, 1959) and recently to the United States (Hoffman, Dunbar, and Bradford, 1962). Likewise, Ichthyophthirius multifilis and Lernaea cyprinacea have been spread to many parts of the world by transfer of aquarium, sport, and food fishes. Protozoa which require specific intermediate hosts, such as leeches, will probably not be so easily transferred to new geographic areas and there may be other limiting factors.

On the other hand, morphologically indistinguishable species of Trichodina, T. fultoni Davis, and T. sp. (T. nigra?) have been found on different hosts in Europe and North America. Assuming that host specificity is involved, proof of physiological identity would have to be established by cross-infection experiments. The occurrence of a trichodinid on a new host in a remote geographic area alone should not support the establishment of a new species. Lom (1962) gave the provisional name $T$. domerguei f. maris-negri to a trichodinid from the skin of a marine fish, Gaidropsis mediterranaeus. Because of its marine occurrence, Lom hesitated at that time to identify it as $T$. domerguei f. magna; however, it is quite possible that it will now prove to be T. fultoni, found in a different geographic area, different

$\leftarrow \quad$ Trichodinids from North American fishes. Figunes A to F. Trichodina fultoni.

A. Specimen just before cell cleavage with the central clear area dividing in two. B. Daughter cell with only half of the original number of denticles. The clear area in the center has disappeared; around the denticulate ring a new ring is originating. C. Specimen with two rings, the old inner one in resorption, the outer new in formation. D. Later stage, the central clear area again formed. E. Mature ciliate, the argentophile grains in the clear area, as seen in Figure D, stain in outline only. F. Final stage, argentophilic grains reduced to "rings." 
host, and even under different conditions of salinity.

The supposed distribution on two continents of the present two trichodinids is supported by other examples-the cosmopolitan distribution of Trichodina pediculus on different species of Hydra; the myxosporidian Myxidium lieberkuehni in Esox lucius in Eurasia (Barysheva and Bauer, 1957: 107) and North America (Kudo, 1920: 107); another myxosporidian, Henneguya salminicola in salmon of North America and Europe (Shulman, 1958); and an acanthocephalan, Neoechinorhynchus rutili in many fish (Van Cleave and Lynch, 1950). As far as we know, the fish hosts of these parasites were not transferred intercontinentally before the parasites were reported from both continents. Since these parasites do not infect birds, they would not have been transferred by this means, as are some fish helminths which live as adults in piscivorous birds.

\section{NORTH AMERICAN TRICHODINIDS}

It is not the purpose of this report to review the trichodinids of the world or even North America. The last review of the North American forms was that of Uzmann and Stickney (1954). However, we would like to present a brief list of the species found in North America for comparison with those of Europe. Two very distinct species, Vauchomia renicola (Mueller, 1932) and V. nephritica Mueller, 1938, are found in the urinary systems of Esox niger and E. masquinongy, respectively (Mueller, 1938); they are further distinguished by more than two turns of their adoral zones. Trichodina myakkae Mueller, 1937 is transferred to Trichodinella because of its short adoral zone, shape of the denticles, etc. (see Lom, 1963); we suggest that it be reexamined by the silver-impregnation method and Trichodinella epizootica (Raabe, 1950) compared with it. Trichodina truttae Mueller, 1937 is the largest species (up to $140 \mu$ in diameter) and clearly differs from our findings; silverimpregnated specimens might be profitably compared with T. fultoni Davis, 1947 and T. janovice Lom, 1961. In Mueller's (1937) description, Trichodina pediculus Ehrbg., 1838 is very similar to the typical form found on Hydra, particularly the shape and number of denticles; this form from Micropterus salmoides of the Myakka River and the form from Hydra could well be compared after silver impregnation (Klein's method).

MacLennan (1939) redescribed Trichodina domerguei from several fishes of the Palouse River; however, it possibly does not possess the clear center of the adhesive disc in impregnated specimens, and also other characteristics of $T$. domerguei as described by Raabe (1959) and Dogiel (1940). Other features of $T$. domerguei noted and illustrated by MacLennan fit the description of several other species as well (number of denticles, diameter of adhesive disc) and cannot be used for differentiation. Reidentification of the Palouse River species will be difficult since MacLennan himself pointed out the lack of host specificity of this species. Trichodina guberleti MacLennan, 1939 was described briefly and it may not be possible to compare it with similar species. The distinctive character between these two species, relation of length of the marginal cilia (cirri) to the length of the aboral membranellous wreath, is of little value since there are numerous other species with the same length relation of these ciliary organelles. Thus, both species will unfortunately be designated as nomina nuda.

Though Davis (1947) did not employ impregnation methods, the descriptions of urceolarids in his paper are comprehensive enough to identify many of them in the future.

T. discoidea Davis, 1947 and T.tumefaciens Davis, 1947 have already been discussed in this paper. It would be desirable to reexamine these two and also T. californica Davis, 1947, T. vallata Davis, 1947, and T. platyformis Davis, 1947 from the original localities. Perhaps $T$. vallata would be more easily recognized because of the elevated ridge of the adoral ciliary zone.

The remainder of Davis' (1947) species should be removed from Trichodina. Due to the degree of development of their buccal structures and denticle shape (cf Lom, 1963) they belong to Trichodinella or Tripartiella. T. symmetrica Davis, 1947 apparently involves two species and from his precise illustrations it is evident that there are also two genera involved-Trichodinella (without inner denticle thorns) and Tripartiella (with inner denticle thorns). A comparison of Tripartiella 
bulbosa (Davis, 1947) and T. bursiformis (Davis, 1947) with species described from Europe would be useful; such a discussion is beyond the scope of this paper, and to be fruitful, would require new collections.

We hope that this article will lead to future research on trichodinids from North America, to elucidate not only the number of North American species, but also their relations to the European species.

\section{LITERATURE CITED}

Barysheva, A. F., AND O. N. Bauer. 1957. Fish parasites of Lake Ladoga. In Petruschevski, G. K. (ed.), Parasites and diseases of fish. Bull. All-Union Sci. Res. Inst. Fresh-water Fisheries. Vol. 42 (English translation by OTS, U. S. Dept. Commerce, PST No. 105, 338 p.).

BaUER, O. N. 1959. Parasites of freshwater fish and the biological basis for their control. Bull. State Sci. Res. Inst. Lake and River Fish. Vol. 49 (English translation by OTS, U. S. Dept. Commerce, PST No. 622, 236 p.).

Davis, H. S. 1947. Studies on the protozoan parasites of fresh-water fishes. U. S. Dept. Interior, Fishery Bull., Washington 51: 1-29.

Dogiel, V. A. 1940. On the classification of the genus Trichodina. (In Russian.) Trudy Leningradskogo Obs. Jestestvorspytatelei 68: 831.

Hoffman, G. L., C. E. Dunbar, and A. Bradford. 1962. Whirling disease of trouts caused by Myxosoma cerebralis in the United States. USFWS, Spec. Sci. Rep.-Fish. No. 427, 15 p.

Kudo, R. 1920. Studies on Myxosporidia. A synopsis of genera and species of Myxosporidia. Ill. Biol. Monog. 5: 1-265.

LOM, J. 1958. A contribution to the systematics and morphology of endoparasitic trichodinids from amphibians, with a proposal of uniform specific characteristics. J. Prot. 5: 251-263. 1961. Ectoparasitic trichodinids from freshwater fish in Czechoslovakia. Acta Soc. Zool. Bohemoslov 25: 215-228.

1962. Trichodinid ciliates from fishes of the Rumanian Black Sea coast. Parasitology 52: $49-61$.

. 1963. The ciliates of the family Urceolariidae inhabiting gills of fishes (Trichodinella group). Acta Soc. Zool. Bohemoslav 27: 7-19.

MacLennan, R. F. 1939. The morphology and locomotor activities of Cyclochaeta domerguei Wallengren (Protozoa). J. Morph. 65: 241255.

Mueller, J. F. 1937. Some species of Trichodina (Ciliata) from freshwater fishes. Tr. Am. Micr. Soc. 56: 177-184.

- 1938. A new species of Trichodina (Ciliata) from the urinary tract of the muskalonge, with a repartition of the genus. J. Parasit. 24: 251-258.

RAABE, Z. 1959. Trichodina pediculus (O. F. Müller, 1786, Ehrenberg, 1838) et Trichodina domerguei (Wallengren, 1897). Acta Parasit. Polon. 6: 189-202.

Shulman, S. S. 1958. Zoogeography of parasites of USSR freshwater fishes. In Dogiel, V. A., G. K. Petrushevski, and Yu. I. Polyanski (ed.), Parasitology of fishes. (English translation, Oliver and Boyd, 284 p.)

UzmanN, J. R., and A. P. Stickney. 1954. Trichodina myicola n. sp., a peritrichous ciliate from the marine bivalve Mya arenaria L. J. Prot. 1: 149-155.

Van Cleave, H. J., and J. E. Lynch. 1950. The circumpolar distribution of Neoechinorhynchus rutili, an acanthocephalan parasite of fresh-water fishes. Tr. Am. Micr. Soc. 69: 156-171. 